\title{
S. B. Boyd Campbell, M.C.
}

Dr. Boyd Campbell died at his home in Ballycastle on 28 February 1971 aged 8I. Samuel Burnside Boyd Campbell was born in India of Irish Presbyterian missionary parents. $\mathrm{He}$ was educated at Foyle College, Londonderry, and Edinburgh University, where he qualified M.B. in I9I2. He crowned a brilliant undergraduate career by gaining first place and a first-class honours degree. After the usual resident appointments at the Royal Infirmary he entered practice in Belfast.

The 36th Ulster Division was formed on outbreak of the 1914 war, and he was among the first volunteers. His main attachment was to I08th Field Ambulance, R.A.M.C., with which he followed the harsh and bloody fortunes of the division, including the 1916 Somme battles. His untiring and selfless devotion to the tasks in hand was recognized by grant of the Military Cross in 19I8.

Back in civilian life he gained the F.R.C.P. diploma in 1919, and was fortunate to be attached to Professor J. E. MacIlwaine's unit at the Royal Victoria Hospital, Belfast. MacIlwaine was the pioneer cardiologist in the Belfast school. Campbell became outpatient physician in 1922; by then his interest in cardiology was firmly established, and on MacIlwaine's untimely death Campbell fell heir to his unit. They were both members of the Cardiac Club, which eventually burgeoned into the British Cardiac Society. They collaborated on several projects, including a clinical evaluation of bundle-branch block.

As a teacher Boyd Campbell had tremendous student appeal, and his weekly talk-in for final-year students was invariably packed out. With the young, whether patients, clerks, or residents, he was always sympathetic and helpful; his interest in their subsequent careers never flagged. He built up an extensive consulting practice, where his easy but efficient manner gained him the confidence of practitioners and patients.

A tall and athletic figure, Boyd Campbell

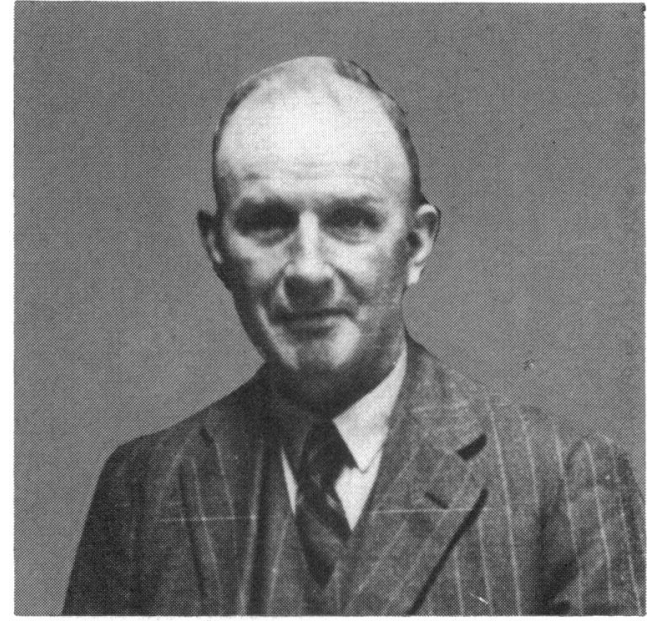

stood out in any gathering. He was a Rugby football enthusiast, and achieved Varsity and International honours while a student.

He retired from practice in 1954 and moved to Ballycastle, where he created a well-nigh perfect garden; many members have been privileged to partake of his hospitality there. Unfortunately his wife did not live to share the enjoyment of his retirement, but the visits of his son, Dr. W. A. B. Campbell, a paediatrician, his three daughters, and grandchildren were a great solace.

He looked forward to and thoroughly enjoyed the Society's meetings, and was Chairman at the Belfast meeting in 1949. He was a Council member from 1947 to 1951 .

Boyd Campbell was not overmuch addicted to public speaking or adding to the burden of medical literature, but, within a coterie of familiars, he was witty, informed, and accurate but scrupulously fair in assessment of men and things. Strong in his enthusiasms and prejudices, he was a man of inflexible principles, but always a warm-hearted, generous, and loyal friend.

T. H. Crozier 